British Journal of Education

Vol.8, Issue 7, pp.32-43, August 2020

Published by ECRTD- UK

Print ISSN: ISSN 2054-6351: Online ISSN: ISSN 2054-636X

\title{
CORRELATION BETWEEN EMPLOYEES' JOB PERFORMANCE AND MANAGEMENT LEADERSHIP STYLE IN TERTIARY INSTITUTIONS IN LAGOS STATE
}

\author{
Ajimuse Muyiwa Sunday (Ph.D) \\ Department of Educational Management and Business Studies \\ Faculty of Education, Federal University, Oye Ekiti
}

\begin{abstract}
The study investigates the correlation between employees' job performance and management leadership styles in tertiary institutions in Lagos state. Which comprises of university of lagos state, Akoka (UNILAG), Lagos state university, Ojo (LASU), Yaba college of Technology (YABATECH) and Adeniran Ogunsanya college of Education, Otto-Ijanikin (AOCEOD). The research design adopted is descriptive research design and was guided by four research questions and four research hypotheses. The population for the study comprised of all academic and nonacademic staff in tertiary institutions owned and financed by both state and federal government in four tertiary institutions out of six (6) of both state and federal public tertiary institutions in Lagos state through purposive sampling technologies Fifty (50) academic and Fifty (50) non-academic staffs were selected through simple random sampling techniques from each of the four (4) tertiary institutions chosen for the study. In one hundred (100) respondents from each tertiary institution with the grand total of four hundred (400) respondents. The research instrument was structured questionnaire tagged 'Questionnaire on Employees' Job Performance and Management Leadership Style" (QEJPMLS) with the twenty (20) items. The data collected were analyzed using percentage and the pearson product moment correlation co-efficient test the significant correlation of the hypotheses at 0.05 level of significant. The findings of the study revealed that there is a correlation between employees job performance and autocratic leadership style at $(R-$ cal value 0.097, $R$-table value 0.81, $D F=4$, level of sig. $=0.05)$. And there is a correlation between employees' job performance and democratic leadership style at $(R$-cal value 0.96, $R$-table value 0.81 , level of Sig. $=0.05)$. Also, there is a correlation between employees'style at $(R$-cal value $0.96, R$-table value 0.81, level of Sig. $=0.05)$. Based on the findings of the study, recommendation were given. It was concluded that, autocratic democratic and laissez-faire management leadership style have an impact on the employees' job performance in tertiary institutions in Lagos State.
\end{abstract}

KEYWORDS: correlation, employees', performance, management, leadership style, institutions.

\section{INTRODUCTION}

Organizations in the world over, operate on various facets and are made up of people with different dispositions who work individually or as a group towards the realizations of the goals of the organization. These people in organizations who work to bring about the realization of the organization's objectives are often guided and directed by someone who is charged with the responsibility of influencing their actions towards the realizations of the laid down goals and objective. Also, the approach adopted by the person charged with the responsibility of leading 
British Journal of Education

Vol.8, Issue 7, pp.32-43, August 2020

Published by ECRTD- UK

Print ISSN: ISSN 2054-6351: Online ISSN: ISSN 2054-636X

others in an organization, more often than not determines the effort put into the job by those upon whom he is appointed to lead.

The approach adopted by a leader to a large extent may considerably affect the job performance of employees. He/ She is responsible to as a leader. This is because the leader influences others in a group to achieve goals and objectives. In the word of Bedian (2014) leadership is act of influencing individual or group activities towards the achievement of organization goals. Traditionally, employees job performance in organization are usually linked with incentives, pay in particular and availability of the right equipment and other materials, with little or no attention to the feeling of the members of the organization towards the leadership style adopted by management.

This could be viewed from the works of the father of scientific management school of thought Fredrick Winslow Taylor, who sees man as a rational being that would perform more task as more incentives are given to him. Also, Douglas McGregor in his theory X sees man as naturally lazy and needs to be kicked in the ass for him to perform his task effectively. However, the emergence of the human relation school of thoughts by Elton Mayor and his counterparts, brought about the consideration of the importance of people in the organization and the need to many individual objectives with organizational objectives.

Thus, the relationship between traditional management leadership approach of controlling the activities of others and the new approach of a leader as a motivator, enabler and facilitator of talent and capacity, building of employees need to be assessed in order to find out the relationship between management leadership style and employees job performance and to ascertain the most appropriate style to be adopted by leaders in various organization, particularly tertiary institutions. Leadership is of a great importance in every organization if the goals of the organization are to be achieved. This is because any group of people or organization who do not have a leader is like a ship sailing without its compass as it will not know the direction to take. Africa is in crisis today because of leadership. Business, industry, government, labour, education, and the church are all starving for effective leadership. There are many people filling administrative positions but the need is for true leaders who are able to help the organization realize their goals and objectively and efficiently.

Every society and organization needs to continuously use leaders who possess the required skills in order to accomplish their laid down objectives. Tertiary institutions are not left out of this. The administrative structure of most tertiary institutions connotes the strong presence of leadership in all firms. We have the council, the senate, post graduate school board, the faculty board and department board. At various levels of hierarchy there are leaders who take major decisions for these tertiary institutions. Tertiary institutions are set up train technical, middle-level and upper level manpower. Leadership is any organization determines the overall wellbeing of the organization.

According to Thomas (2007) which stated that the tradition perspective of management as a controlling and directing function, has been under attack. Many of the world's leading 
British Journal of Education

Vol.8, Issue 7, pp.32-43, August 2020

Published by ECRTD- UK

Print ISSN: ISSN 2054-6351: Online ISSN: ISSN 2054-636X

organizations now want their people to be self-directed. Words such as empowerment and innovation, personal drive are used, thus require people to be trusted to management. The new model of management leadership requires people with a high level of interpersonal skills and possess the ability to communicate, motivate and mobilize others towards common goals. Also, the ability to create a positive working atmosphere in which people feel free to communicate their ambitions, ideals as well as employees who feel comfortable raising concerns and challenging others even their boss is inevitable under the new model.

Organizational leadership and management style are important factors that affects the level of employees' performance on the job. According to Akinlabi (2005), leadership is the process by which leaders induce follower to act for certain goals that represent the values and the motivations, the wants and needs the aspirations and expectations of both leaders and followers. Also, in the words of Robins (2012), leadership is the ability to influence a group towards the achievement of organizational goals. A leader therefore could be likened to a compass which steers the affairs of the organizations as the compass guides a ship in its direction.

Over the years, researchers have identified various theories of leadership. According to Adeyemi (2010), some of the theories that have been identified by researchers include; the trait theory, behavioral theory, situational theory, contingency theory and the path goal theory. The trait theory focuses on the personal trait of a leader such as appearance, height, initiative, aggressiveness, enthusiasm self-confidence, drive, interpersonal skill and administrative ability. The situational theory views leaders as the products of given situations and that leadership is strongly affected by the situation from which the leader emerges and in which he operates.

The behavioral theory could be viewed from the perspectives these are: (a) Job centered (b) Employee centered.

The job-centered leaders' practices close supervision. The contingency theory is the combination of the trait theory and the situation theory. The theory implies that leadership is a process in which the ability of a leader to exercise influence depends upon the group task situation and the degree to which the leader's personality fit the group.

From the foregoing, leadership could be viewed as the process through which a person, persons or group influence the activities and actions of others towards the achievement of organizational or group goals. In the words of Abari \& Mohammed (2010), leadership style is a leader's typical way of behavior towards group members. Leadership styles vary according to individuals, the nature of the followers as well as the nature of the nature of the organization itself. Three major styles of leadership as identified by Abari and Mohammed (2010) include autocratic, democratic and laissez faire leadership styles.

The autocratic leadership style is also referred to as the authoritarian style of leadership. The autocratic leader directs group on the way things should be done. He or she does not maintain clear channel of communication between him/ her and her subordinate. Also, decision making resides solely on the autocratic leader directs group members on the way things should be done. He or she neither delegates authority nor permit subordinates to participate in public making. 
The democratic style of leadership emphasizes group and leader participation in the making of organizational or group policies. The democratic leader consult with the members of the group and decisions about organizational matter are taken after due consultation and communication with the various groups in the organization. The leader attempts as much as possible to make each individual feel that he is an important member of the organization communication is much directional while ideas are exchanged between the subordinates and the leader. In this type of leadership, a high degree of staff morale is enhanced.

Laissez-faire leadership style: This type of leadership style allows subordinates or members of the group to take decision freely, with little or no participation by the leader. The subordinates are given freedom to act and do things the way they like. The role of the leader is just to supply materials. The leader does not interfere with or participate in the course of events determine by the group. It is against this background that the study was designed to investigate the correlation between employees' job performance and management leadership style in tertiary institutions in Lagos state.

\section{Statement of the Problem}

Management is one of the key issues affecting our tertiary education today, the various management leadership styles adopted by various management of higher education determines the performance of the employees both academic and non-academics. Higher institution in Nigeria has witnessed an incessant closure due to the management leadership styles, labour union strikes and conflicts has been reoccurring, for instance, all the union such as NASU,SSANU and ASUU in Lagos State University were on conflict for almost 7 to 8 months due to leadership management style in the university. This has affected employee job performance in the university. It is as a result that this study was designed to examine the correlation between employees' job performance and management leadership style in tertiary institutions in Lagos State.

\section{Purpose of the study}

The study examined if there is any correlation between employees job performance and management leadership style in tertiary institutions in Lagos state. This study is also aimed to:

- Examines correlation between autocratic leadership style and employees' job performance in tertiary institutions in Lagos State.

- Investigate if there is any correlation between democratic leadership styles and employee's job performance in tertiary institutions in Lagos state.

- Identity whether laissez-faire leadership style would enhance employees' job performance in tertiary institutions in Lagos state.

- Ascertain whether management leadership style has any correlation with employees' creativity on their job in tertiary institutions in Lagos state.

\section{Research Questions}

The following research questions were formulated to enhance the study based on the problem under investigation. 
1) Is there any correlation between employees' job performance and autocratic leadership style in tertiary institutions in Lagos state?

2) Does any correlation exist between employees' job performance and democratic leadership style in tertiary institutions in Lagos state?

3) Will there be any correlation employees' job performance and laissez-faire leadership style in tertiary institutions in Lagos state?

4) To what extent is the management leadership styles has improve employees' creativity on their job in tertiary institutions in Lagos state?

\section{Research Hypotheses}

The following null hypotheses were formulated to examine the correlation between employees' job performance and management leadership in tertiary institutions in Lagos State.

- There is no correlation between employees' job performance and autocratic leadership style in tertiary institutions in Lagos state.

- There is no correction exist between employees' job performance and democratic leadership style in tertiary institutions in Lagos state.

- There is no correlation between employees' job performance and laissez-faire leadership style in tertiary institutions in Lagos state.

- There is no correlation between employees' creativity on their job and management leadership styles in tertiary institutions in Lagos state.

\section{RESEARCH METHODOLOGY}

The chapter provides the details of the research methodology adopted in the study. The methodology was discussed under the following headings: research design, population of the study, sample and sampling techniques, research instrument and instrumentation, others subheadings are validity of the instrument, administration of instrument and method of data analysis.

\section{Research Design}

This study adopted a descriptive and correlation research design. The study considered the correlation between employees' job performance and management leadership style in tertiary institutions in Lagos state.

\section{Population of study}

The population for this study consists of all employees in tertiary institutions from six (6) in Lagos state. It made up of all academic and non-academic staff in all the tertiary institutions in Lagos state.

\section{Sample and Sampling Technique}

The study sample was drawn from four (4) tertiary institutions out of six of both state and federal public tertiary institutions in Lagos state through purposive random sampling. These tertiary institutions are University of Lagos (Akoka), Lagos State University, Ojo, Yaba College of Technology and Adeniran Ogunsanya College of Education Oto-Ijanikin Lagos state. 
In each of the tertiary institutions, fifty (50) academic and fifty (50) non-academic staffs were selected through simple random sampling from each of the four tertiary institutions. In all, a total of one hundred respondents were selected from each tertiary institution with the grand total of four hundred (400) respondents.

\section{Research Instruments}

The research instrument employed for this study was tagged 'Questionnaire Employees' Job Performance and Management Leadership Style (QEJPMLS). The questionnaire was divided into two parts of section A and B. section A items was used to elicit information on the personal bio data of respondents such as age, gender, marital status, year of working experience, educational qualifications and so on. While section B was used to sought information on the employees' job performance and management leadership style.

A twenty (20) self-structured items of questions were designed to seek information on employees' job performance and management leadership style in tertiary institutions in Lagos state. The Likert four point scale was used to sample the opinion of the respondents as stated. Strongly Agree (SA), Agree (A) 3, Disagree (D) 2 and Strongly Disagree (SD) 1

\section{Validity of Instrument}

The instrument was developed by researcher through the assistance of some experts in the field of education. It was letter presented to the researcher's supervisor for structural correlations in order to ascertain both the content and face validity of the instruments.

\section{Reliability of Instrument}

In order to ascertain whether the instrument consistently measure what its meant to measure, the researcher subjected the instrument to test-re-test method of reliability by administered the instrument to twenty (20) respondents and later re-administered to the same respondents after two weeks of the first administered. The outcome of the results shows that the instrument is reliable.

\section{Administration of the Instrument}

The instrument was personally administered to the respondents in each of the selected tertiary institutions by the researcher with the help of two research assistants. The questionnaires were collected on the same day to ensure high percentage of returns. It was observed that the percentage of was hundred percent.

Method of Data Analysis

The data collected were analyzed through the pearson product Moment Correlation Coefficient. The statistical formula is given below.

$$
\mathrm{rp}=\frac{N \cdot \Sigma x y-(\Sigma x)(\Sigma y)}{\sqrt{\left[\mathrm{N} \cdot \Sigma^{\mathrm{x} 2}-(\Sigma \mathrm{x})^{2}\right]\left[\mathrm{N} \Sigma \mathrm{y}^{2}-(\Sigma \mathrm{y})^{2}\right]}}
$$

Where rp - Pearson Product Moment Correlation Co-efficient

$\mathrm{X}$ - Variable $\mathrm{X}$ independent variable

Y - Variable Y dependent variable

$\mathrm{X}_{2}$ - Square of variable $\mathrm{X}$

$\mathrm{Y}_{2-}$ Square of variable $\mathrm{y}$

$\mathrm{N}$ - Number of items in the variable 
$\Sigma-$ Summation

\section{FINDING AND DISCUSSING}

This chapter contains data presentation, analysis and interpretation of results collected for the purpose of this study. A total of four hundred (400) questionnaires were administered to the both academic and non-academic staff of selected tertiary institutions in Lagos state. However, all the total of four hundred (400) questionnaire were duly filled and returned which constitute hundred percent of the questionnaire administered. The analysis of items on the section $\mathrm{A}$ of the questionnaire was analyzed using simple percentage method. The purpose is to determine the demographic data of the respondents participated in the study.

\section{Demographic Data}

Table 1: Distribution of respondents by Gender

\begin{tabular}{|l|l|l|}
\hline Gender & Frequency & Percentage (\%) \\
\hline Male & 250 & 62.5 \\
\hline Female & 150 & 37.5 \\
\hline Total & 400 & 100 \\
\hline
\end{tabular}

Source: Field Survey, 2020

From the above table result shows that $62.5 \%$ were male while $37.5 \%$ were female. This implies that there were more male than female respondents in the sample.

Table 2: Distribution of respondents by Age

\begin{tabular}{|l|l|l|}
\hline Age & Frequency & Percentage $\mathbf{( \% )}$ \\
\hline $21-30$ years & 35 & 8.75 \\
\hline $31-40$ years & 260 & 65.0 \\
\hline $40-50$ years & 79 & 19.75 \\
\hline 51 years and above & 26 & 6.5 \\
\hline Total & 400 & 100 \\
\hline
\end{tabular}

\section{Source: Field Survey, 2015}

From the table, age distribution of the respondents shows that $8.75 \%$ fell between $21-30$ years of age, $65.0 \%$ were within the range of $19.75 \%$ were between $40-50$ years old and $6.5 \%$ were 51 years and above. This shows that the majority of the respondents were within the age of $31-40$

Table 3: Distribution of respondents by status

\begin{tabular}{|l|l|l|}
\hline Status & Frequency & Percentage (\%) \\
\hline Academic staff & 200 & 50 \\
\hline Non-Academic staff & 200 & 50 \\
\hline Total & 400 & 100 \\
\hline
\end{tabular}

Source: Field Survey, 2015

From the above table, the result shows that $50 \%$ are academic staff while $50 \%$ were non-academic staff. This revealed that both academic and non-academic staff had equal chance in the study. 
Print ISSN: ISSN 2054-6351: Online ISSN: ISSN 2054-636X

Table 4: Distribution of respondents by years of working experiences

\begin{tabular}{|l|l|l|}
\hline Years of work Experience & Frequency & Percentage (\%) \\
\hline $1-5$ & 10 & 2.5 \\
\hline $6-10$ & 31 & 7.75 \\
\hline $11-15$ & 10 & 27.25 \\
\hline $16-20$ & 100 & 25.0 \\
\hline $21-25$ & 100 & 25.0 \\
\hline $26-30$ & 40 & 10.0 \\
\hline 31 years and above & 10 & 2.5 \\
\hline Total & 400 & 100 \\
\hline
\end{tabular}

Source: Field Survey, 2015

From the above table, the result shows that most of the respondents' years of work experience of $1-5$ years are $2.5 \%, 6-10$ years were $7.75 \%, 11-15$ years were $27-25 \%$, while both $16-20$ years and $21-25$ years were $25.0 \%$ respectively. Also $26-30$ years were $10-0 \%$ and 31 years and above were $2.5 \%$ of the total respondents.

Table 5: Distribution of respondents by Marital Status

\begin{tabular}{|l|l|l|}
\hline Marital Status & Frequency & Percentage (\%) \\
\hline Single & 80 & 20.0 \\
\hline Married & 300 & 75.0 \\
\hline Separated & 20 & 5.0 \\
\hline Total & 400 & 100 \\
\hline
\end{tabular}

Source: Field Survey, 2015

From the above table, it shows that $20.0 \%$ of the respondents were single, while $75.0 \%$ were married and $5.0 \%$ were separated of the total respondents.

Table 6: Distribution of respondents by academic qualification

\begin{tabular}{|l|l|l|}
\hline Academic Qualification & Frequency & Percentage (\%) \\
\hline WASSCE/SSCE/NABTEB & 120 & 30.0 \\
\hline NCE/ND/HND & 10 & 2.5 \\
\hline B.SC/BA/B.E & 30 & 7.5 \\
\hline M.SC/MA/M.ED/MBA/MPA & 100 & 25.0 \\
\hline M.PHIL/P.HD & 140 & 35.0 \\
\hline TOTAL & 400 & 100 \\
\hline
\end{tabular}

\section{Source: Field Survey, 2015}

From the above table, it shows that $30.0 \%$ of the respondents had WASSCE/SSCE/NABTEB, $2.5 \%$ had NCE/ND/HND, and $7.5 \%$ had B.SC/B.A/B.ED, while $25.0 \%$ had M.SC/MA/M.ED/MBA/MPA and 35.0\% had M.PHIL/ P.HD of total respondents.

Test of Hypotheses

\section{Hypothesis One}

There is no correlation between employees' job performance and autocratic leadership style in tertiary institutions in Lagos state. 
British Journal of Education

Vol.8, Issue 7, pp.32-43, August 2020

Published by ECRTD- UK

Print ISSN: ISSN 2054-6351: Online ISSN: ISSN 2054-636X

Table 7: Table showing summary result of correlation between employees' job performance and autocratic leadership style.

\begin{tabular}{|c|c|c|c|c|c|c|c|}
\hline Variable & $\mathbf{N}$ & Sums & \begin{tabular}{|l}
$\begin{array}{l}\text { Level } \\
\text { of Sig. }\end{array}$ \\
\end{tabular} & DF & $\begin{array}{l}\text { R-Cal } \\
\text { Value }\end{array}$ & $\begin{array}{l}\text { R-Table } \\
\text { Value } \\
\end{array}$ & Decision \\
\hline \multirow{2}{*}{$\begin{array}{l}\text { Autocratic } \\
\text { Leadership Style } \\
\text { (X) }\end{array}$} & 5 & $\begin{array}{l}\Sigma \mathrm{x}=3360 \\
\Sigma \mathrm{x}^{2}=2649600\end{array}$ & & & & & \\
\hline & & $\Sigma x y=1161600$ & 0.05 & 4 & 0.97 & 0.81 & Rejected \\
\hline $\begin{array}{l}\text { Employees' Job } \\
\text { Performance (Y) }\end{array}$ & 5 & $\begin{array}{l}\Sigma \mathrm{y}=1960 \\
\Sigma \mathrm{y}^{2}=833600\end{array}$ & & & & & \\
\hline
\end{tabular}

\section{See detailed calculation in Appendix 2A}

The table 7 above shows the summary of the computation of pearson product correlation between employees' job performance and autocratic leadership style in tertiary institutions in Lagos state. The result shows that they are significant at 0.05 level of significant and degree of freedom 4 . Therefore, since the calculated value of 0.97 is greater than table value 0.81 , the hypothesis that state that there is no correlation between employees' job performance and autocratic leadership style in tertiary institutions in Lagos state is hereby rejected and alternative hypothesis is upheld. This implies that there is a correlation between employees' job performance and autocratic leadership style in tertiary institutions in Lagos state.

\section{Hypothesis Two}

There is no correlation between employees' job performance and democratic leadership style in tertiary institutions in Lagos state.

\begin{tabular}{|l|l|l|l|l|l|l|l|}
\hline Variable & N & Sums & $\begin{array}{l}\text { Level } \\
\text { of Sig }\end{array}$ & DF & $\begin{array}{l}\text { R-Cal } \\
\text { value }\end{array}$ & $\begin{array}{l}\text { R-Table } \\
\text { value }\end{array}$ & Decision \\
\hline Democratic & 5 & $\Sigma \mathrm{x}=3390$ & & & & & \\
Leadership Style (X) & & $\Sigma \mathrm{x}^{2}=2520900$ & & & & & \\
\hline & & $\Sigma \mathrm{xy}=930600$ & 0.05 & 4 & 0.96 & 0.81 & Rejected \\
\hline $\begin{array}{l}\text { Employees' Job } \\
\text { Performance (Y) }\end{array}$ & 5 & $\begin{array}{l}\Sigma \mathrm{y}=1620 \\
\Sigma \mathrm{y}^{2}=661200\end{array}$ & & & & & \\
\hline
\end{tabular}

\section{See detailed calculation in Appendix 2B}

The table 8 above shows that correlation between employees' job performance and democratic leadership style are significant at 0.05 level of significance and degree of freedom 4 . Therefore, since the calculated value of 0.96 is greater than table value 0.81 , then the hypothesis that there is no correlation between employees' job performance and democratic leadership style in tertiary institutions in Lagos State is hereby rejected and alternative hypothesis is accepted. This implies 
that there is a correlation between employees' job performance and democratic leadership style in tertiary institutions in Lagos State.

\section{Hypothesis Three}

There is no correlation between employees' job performance and laisser-faire leadership style in tertiary institutions in Lagos State

Table 9: Table showing summary result of correlation between employees' job performance and laisser-faire style

\begin{tabular}{|l|l|l|l|l|l|l|l|}
\hline Variable & N & Sums & $\begin{array}{l}\text { Level } \\
\text { of Sig. }\end{array}$ & DF & $\begin{array}{l}\text { R-Cal } \\
\text { value } \\
\text { value }\end{array}$ & $\begin{array}{l}\text { R-Table } \\
\text { Decision }\end{array}$ \\
\hline $\begin{array}{l}\text { Laissez-faire } \\
\text { Leadership Style (X) }\end{array}$ & 5 & $\begin{array}{l}\Sigma \mathrm{x}=2430 \\
\Sigma \mathrm{x}^{2}=1311300\end{array}$ & & & & & \\
\hline $\begin{array}{l}\text { Employees Job } \\
\text { Performance (Y) }\end{array}$ & 5 & $\begin{array}{l}\Sigma \mathrm{xy}=950100 \\
\Sigma \mathrm{y}^{2}=1082500\end{array}$ & 0.005 & 4 & 0.90 & 0.81 & Rejected \\
\hline
\end{tabular}

\section{See detailed calculation in Appendix 2C}

The table 9 above shows that correlation between employees' job performance and laissez-faire leadership style are significant at 0.05 level of significance and degree of freedom 4 . Therefore, since the calculated value of 0.90 is greater than table value 0.81 , then the hypothesis that state that there is no correlation between employees' job performance and laissez-faire leadership style in tertiary institutions in Lagos state is hereby rejected and alternative hypothesis is upheld. This implies that there is a correlation between employees' job performance and laissez style in tertiary institutions in Lagos state.

\section{Hypothesis Four}

There is no correlation between employees' creativity on their job and management leadership style in tertiary institutions in Lagos state.

Table 10: Table showing summary result of correlation between employees' creativity on their job and management leadership style

\begin{tabular}{|l|l|l|l|l|l|l|l|}
\hline Variable & $\mathbf{N}$ & Sums & $\begin{array}{l}\text { Level } \\
\text { of Sig. }\end{array}$ & DF & $\begin{array}{l}\text { R-Cal } \\
\text { value }\end{array}$ & $\begin{array}{l}\text { R-Table } \\
\text { value }\end{array}$ & Decision \\
\hline $\begin{array}{l}\text { Management } \\
\text { Leadership Style (X) }\end{array}$ & 5 & $\begin{array}{l}\Sigma \mathrm{x}=3936 \\
\Sigma \mathrm{x}^{2}=3358296\end{array}$ & & & & & \\
\hline & & $\Sigma \mathrm{xy}=1164552$ & 0.05 & 4 & 0.98 & 0.81 & Rejected \\
\hline $\begin{array}{l}\text { Employees } \\
\text { Creativity (Y) }\end{array}$ & 5 & $\begin{array}{l}\Sigma \mathrm{y}=1582 \\
\Sigma \mathrm{y}^{2}=526724\end{array}$ & & & & & \\
\hline
\end{tabular}

See detailed calculation in Appendix 2D 
The table 10 above shows that correlation between employees' creativity on their job and management leadership styles are significant at 0.05 level of significance and degree of freedom 4. Therefore, since the calculated value of 0.98 is greater than table value 0.81 , then the hypothesis that state that there is no correlation between employees' creativity on their job and management leadership style in tertiary institutions in Lagos state is hereby rejected and alternative hypothesis is upheld. This implies that there is no correlation between employees' creativity on their job and management leadership style in tertiary institutions in Lagos state.

\section{DISCUSSION OF RESULTS}

From the highlights of the four hypotheses presented above, all the questionnaire samples retrieved indicated that employees' job performance and creativity in tertiary institutions in Lagos state improve through various forms of management leadership styles. However, the difference in the calculated value and the table value suggested that there is a correlation between employees' job performance and management leadership style in tertiary institutions in Lagos state. Hence, most of the sampled respondents strongly believed that with various leadership styles adopted by various managements, these would improve employees' job performance and creativity.

\section{CONCLUSION}

The findings of this study ' it was revealed that the leadership styles of management in school setting helps, facilities and boosts effectiveness and efficiency of the school system . However, it is essential to point out at this juncture that there are differences between the management leadership style with educational and professional qualification and those without qualifications. Therefore, there would be a strained correlation between employees and management if the management leadership style is autocratic. Also, there would be a cordial correlation between the management and employees if leadership style is democratic and the job performance and creativity of employees' would also be influenced by the leadership style of the management.

\section{Recommendations}

The followings are recommended based on the findings of the study

1. Government should ensure that those to be made as a school administrator/manager should only be those who have an ample experience and who can enhance effective leadership style in the school system

2. The school administrator/ manager should endeavor to attend conferences, workshops, seminars, in order to be exposed, gain and acquire leadership knowledge on how effectively they can manage the school as an organization.

3. Administrator/ manager as the head of institutions/schools should create a conducive atmosphere and environment enough to enhance the efficiency of the systems

4. The Administrators / managers should not stay to a particular leadership style 'but apply various leadership styles as the situation arose and demanded. 


\section{References}

Abari A.O. and Mohammed M.O.B. (2010). Fundamentals of Educational Management, Babs Olatunji publishers Lagos.

Adeyemi, T. (2010). Principals' Leadership Styles and Teachers' Job Performance in Secondary Schools in Ondo State, Nigeria.

Journal of Educational Administration and Policy Studies, 2(6) 83-91 Retrieved December, 10, 2011.

Akinlabi, M. (2005). Causal-Factors of Leadership Effectiveness in Male Dominated Work Organizations, Journal of gender and Development, 12(2), 43-52

Ajimuse M.S (2015) Correlation between Employees' job performance and Management Leadership Styles in Tertiary Institutions in Lagos state. M.ED An Unpublished Thesis submitted to the Department of Educational management. Lagos state university.

Bendia, J. (2014). School leadership in an Urban Setting. Retrieved on March 13, 2008. Http://www.self.0x.ac.uk

Robins, K. (1991). Organizational Behaviour Concepts, controversies lewood Cliff N.J. 